\title{
Productivity and Nutritional Trait Improvements of Different Tomatoes Cultivated with Effective Microorganisms Technology
}

\author{
Giuseppina Tommonaro ${ }^{1, *(1)}$, Gennaro Roberto Abbamondi ${ }^{1}$, Barbara Nicolaus ${ }^{1}$, Annarita Poli ${ }^{1} \mathbb{1}$, \\ Costantino D'Angelo ${ }^{2}$, Carmine Iodice ${ }^{1}$ and Rocco De Prisco ${ }^{1}$ \\ 1 National Council of Researches of Italy-Institute of Biomolecular Chemistry (ICB), Via Campi Flegrei, 34, \\ 80078 Pozzuoli, Italy; gennaroroberto.abbamondi@icb.cnr.it (G.R.A.); bnicolaus@icb.cnr.it (B.N.); \\ apoli@icb.cnr.it (A.P.); ciodice@icb.cnr.it (C.I.); roccodeprisco1@virgilio.it (R.D.P.) \\ 2 Department of Medical Biotechnologies, University of Siena, Viale Mario Bracci, 16, 53100 Siena, Italy; \\ costantinodangelo92@gmail.com \\ * Correspondence: gtommonaro@icb.cnr.it; Tel.: +39-0818675029; Fax: +39-0818041770
}

check for updates

Citation: Tommonaro, G.;

Abbamondi, G.R.; Nicolaus, B.; Poli, A.; D'Angelo, C.; Iodice, C.; De Prisco, R. Productivity and Nutritional Trait Improvements of Different Tomatoes Cultivated with Effective

Microorganisms Technology. Agriculture 2021, 11, 112. https:// doi.org/10.3390/agriculture11020112

Received: 16 December 2020

Accepted: 26 January 2021

Published: 1 February 2021

Publisher's Note: MDPI stays neutral with regard to jurisdictional claims in published maps and institutional affiliations.

Copyright: (C) 2021 by the authors Licensee MDPI, Basel, Switzerland. This article is an open access article distributed under the terms and conditions of the Creative Commons Attribution (CC BY) license (https:// creativecommons.org/licenses/by/ $4.0 /)$.

\begin{abstract}
The use of ecofriendly strategies, such as the use of Plant Growth Promoting Bacteria, to improve the yield and quality of crops has become necessary to satisfy the growing demand of food and to avoid the use of chemical fertilizers and pesticides. In this study, we report the effects of an innovative microbial inoculation technique, namely Effective Microorganisms (EM), compared with traditional approaches, on productivity and nutritional aspect of four tomato varieties: Brandywine, Corbarino Giallo, S. Marzano Cirio 3, S. Marzano Antico. Results showed an increase of plant productivity as well as an enhanced antioxidant activity mainly in San Marzano Antico and Brandywine varieties treated with EM technology. Moreover, the polyphenol and carotenoid contents also changed, in response to the plant treatments. In conclusion, the application of $\mathrm{EM}^{\circledR}$ technology in agriculture could represent a very promising strategy in agricultural sustainability.
\end{abstract}

Keywords: tomato; effective microorganisms; agricultural sustainability; antioxidant activity; Plant Growth Promotion Bacteria (PGPB)

\section{Introduction}

According to the data published by the Department of Economic and Social AffairsPopulation Division of the United Nations, the human population was 7.7 billion in 2019 and it is expected to reach 9.7 billion in 2050 and 10.9 billion in 2100 [1]. The worldwide increase in world's population has generated a growing demand of food, and consequently the need of developing innovative techniques to enhance agricultural productivity [2]. Chemical fertilizers, manures, and pesticides represent the conventional strategies adopted to increase crop yields and to preserve the plants from pests [3]. However, the indiscriminate use of these chemical products damages the environment by polluting soil, air, and water [4-7].

The unforeseen harmful effects of chemical fertilizers and pesticides, together with the need of providing enough food to the growing world population, led politicians and researchers to focus on sustainability applied to intensive agriculture. The development of new eco-friendly strategies in intensive agriculture is necessary to counteract environmental, ecological, and health risks.

One of the most promising strategies in agricultural sustainability is the use of Plant Growth Promoting Bacteria (PGPB). Plant associated microorganisms can improve plant growth and health through different processes, generally classified as direct or indirect mechanisms [8]. They can directly act as biofertilizers by increasing the availability of resources that normally remain unavailable for the plants [9]. Indirect microbial PGP traits are essentially based on the "biocontrol" of phytopathogens via different systems, such as the production of one or more antibiotics or enzymes (chinatase, $\beta$-1,3-glucanase, 
protease, lipase) or by the control of virulence factors acting on cell-to-cell communication mechanism known as Quorum Sensing (QS) [10].

Tomato is one of the most valuable crops worldwide. Nowadays it is globally produced, mainly thanks to the development of innovative agricultural techniques and the possibility to control growth conditions in the greenhouses.

Tomato perfectly meets industrial and market requirements, not only because of its pleasant organoleptic characteristics (as flavor, appearance and texture), but also as a result of its versatility. It can be directly commercialized as fresh fruit, but it can also be processed as sauce, powder, paste, juice, etc. Moreover, the importance of tomato is due to its high concentration of biologically active molecules, such as polyphenols, carotenoids (lycopene, $\beta$-carotene), folate and ascorbate (vitamin $C$ ), which makes it highly attractive not only to the agro-food industry, but also in cosmetics and pharmaceuticals [11,12].

Recent studies underlined the association between a diet based on high consumption of fruits and vegetables, with a reduced risk of cardiovascular diseases, cancer, ageing, and other chronic degenerative disorders [13]. Tomato is rich in bioactive phytochemicals whose activities beneficially affect human health because of their antioxidant (free radical scavenging), anti-inflammatory, anticarcinogenic, and antiatherogenic properties [14]. Therefore, new tomato cultivars with an increased bioactive compound level (e.g., lycopene, $\beta$-carotene, and polyphenol content), are considered high-quality "functional foods" because of the enhanced nutritional characteristics $[15,16]$.

Two typical tomato varieties of the Campania region (south of Italy), namely San Marzano and Corbarino were selected for our study. San Marzano was selected for its nutritional features and global commercial importance, especially in processing products (peeled, pureed). In particular, both the ancient variety of this cultivar, named "San Marzano Antico" and the hybrid "San Marzano Cirio 3", designed to improve its cultivation parameters (increased plant productivity and better resistance to diseases), were studied. Corbarino, another typical tomato variety of Campania region, specifically in the Corbara area, has also shown interesting nutritional properties. In particular, the yellow variety (Corbarino Giallo) of this cultivar showed a high content of $\beta$-carotene associated with low levels of lycopene $[17,18]$. Brandywine is a tomato variety typical of North America. It was chosen as foreign tomato variety to be compared with typical Italian varieties.

This study aims to contribute to the discussion on the effectiveness of using PGPB in agriculture. More specifically, the effects of microbial inoculation on four tomato varieties (Brandywine, Corbarino Giallo, S. Marzano Cirio 3, S. Marzano Antico), with a specific EM $^{\circledR}$ biofertilizer (EM-SCHWEIZ AG, Switzerland), were evaluated and compared to the same varieties cultivated with traditional methodologies. Carotenoid and polyphenolic contents, together with the antioxidant activity of lipophilic/hydrophilic/polyphenolic extracts, were selected as biomarkers for fruit quality.

\section{Materials and Methods}

\subsection{Tomato Plants and EM Treatment}

Tomato plants of Brandywine (BW), Corbarino Giallo (CY), San Marzano Cirio 3 (SMC3) and San Marzano Antico (SMA) were grown in an experimental field named 'Vado Cannata', a field in Accadia (Foggia, Southern Italy) presenting very good exposure to sun and water. Seeds of tomato germinated at the end of March 2018; 45-day-old tomato seedlings were transplanted in the 'Vado Cannata' field. The tomato plants (n.100 for each variety) were divided in three groups according the fertilizing techniques utilized during their growth: CONTROL (only water), BIODIN (common fertilizers), and BOK-EM (Bokashi plus EM-1). Sampling of fruits was performed in August 2018 at the maximum of ripening (red ripe for tomato such as San Marzano Cirio 3, San Marzano Antico, and Brandywine or fully yellow for the variety Corbarino Giallo). All tomato fruits were at the same degree of growth and ripening and without injuries. Fruits were counted and weighed. For each varieties, 40 fruits (randomly sampled) were selected and divided in 
two groups that were analyzed separately for chemical-physical parameters and extraction process. Three technical measurements were done for each analysis.

\subsection{Biodynamic Agriculture}

Biodynamic Agriculture (BIODIN) is one of the most important organic agriculture farming systems. This methodology is based on nitrogen fixation by leguminoses, a crop rotation and the use of organic, mainly composted solid manure [19]. The experimental field dedicated to BIODINtreatment was previously used for leguminose (lens, potato) cultivation for two years. Before the tomato seedlings, the soil was enriched with composted solid manure containing about $9 \%$ of minerals (Nitrogen, Phosphorous, Potassium and Magnesium), $38 \%$ of organic carbon, and $11 \%$ of humic acid. After one month, tomato plants of all varieties were planted. The composted solid manure was used as fertilizer every two weeks.

\section{3. $E M^{\circledR}$ Technology}

$\mathrm{EM}^{\circledR}$ (Effective Microorganisms) technology has been described for the first time in 1970 by Prof. Teruo Higa at Ryukyus University in Okinawa [20]. EM ${ }^{\circledR}$ liquid solution included a mix of isolated soil microorganisms, such as lactic (Lactobacillus plantarum, L. casei, Streptococcus lactis) and photosynthetic bacteria (Rhodopseudomonas lalustris and Rhodobacter speroides), yeasts (Saccharomyces cerevisiae and Candida utilis), actinomicetes (Streptomyces albus and S. griseus) and fungi (Aspergillus oryzae, Penicillum sp., Mucor hiemalis, Trichoderma harzianum, and Trichoderma viride).

The experimental field dedicated to $\mathrm{EM}^{\circledR}$ technology was treated, at first, with Bokashi product, bran enriched with $\mathrm{EM}^{\circledR}$ liquid solution (EM-1). The benefit of Bokashi (EM plus organic matter) consists in the ability of the EM to ferment organic matter, thus released nutrients can be used by plants. Two weeks before planting the tomato seedlings, Bokashi was dispersed on the ground, and was mixed in the first $6 \mathrm{~cm}$ of soil. The amount of Bokashi used was $200 \mathrm{~g} \mathrm{mq}^{-1}$ of field. Next, EM-1 (liquid solution) was used on tomato plants starting from their transfer to the open field. Before the use, EM-1 was diluted 1:500 $(v / v)$ in water and sprayed on the plants once every 7 days. The fertilizers application scheme was the same for all varieties.

\subsection{Analysis of Chemical-Physical Parameters}

The total soluble solids (TSS) content of samples, expressed as ${ }^{\circ}$ Brix, was estimated by using refractometer and sucrose (Sigma-Aldrich, Italy) as standard. The total titratable acidity (TA) of samples was evaluated by means of $0.1 \mathrm{~N} \mathrm{NaOH}$ titration up to achieve a $\mathrm{pH}$ of 8.1 value. TA was expressed as grams of acid citric equivalent for $100 \mathrm{~g}$ of fresh product (g CA/100 g FW) [21].

\subsection{Extraction Process}

For the bioactive components evaluation, each sample (100-250 g) was homogenized in a blender and then centrifuged at $13,848 \times g$ for $20 \mathrm{~min}$. The supernatants, consisting of the hydrophilic fraction, were collected and used in the antioxidant assay while pellets were extracted with diethyl ether $(1: 2 w / v ; 20$ min under stirring in the dark, repeated 3 times with fresh solvent) and methanol (1:2 w/v; 30 min under shaking in the dark, repeated 3 times with fresh solvent) with the aim to recover lipophilic and polyphenolic fractions, respectively [11].

\subsection{Antioxidant Activity}

The antioxidant activity was evaluated by using DMPD, DPPH, and ABTS spectrophotometricmethods, which are based on the capacity of different components to inhibit

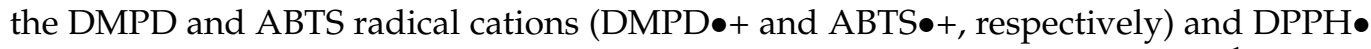
radical [22-24]. The antioxidant capacity was expressed as mg eq Trolox $100 \mathrm{~g}^{-1}$ of fresh product. 


\subsection{Bioactive Compound Contents}

\subsubsection{Polyphenols}

The total polyphenol content was estimated by using the Folin-Ciocalteau method. Briefly, $50 \mu \mathrm{L}$ of Folin-Ciocalteau's phenol reagent, a volume of samples ranging from 10 to $50 \mu \mathrm{L}$ and $800 \mu \mathrm{L}$ of deionized water were accurately mixed. After $1 \mathrm{~min}, 100 \mu \mathrm{L}$ of $20 \%$ sodium carbonate solution was added and further mixed. A final volume of $1 \mathrm{~mL}$ was reached by adding deionized water. Quercetin was used as standard. Samples were kept at room temperature for $2 \mathrm{~h}$ and then the total phenol content was estimated by reading at $\lambda$ 765 nm (DU-Beckman, 5350 Lakeview Parkway South Drive, Indianapolis, IN 46268, USA).

\subsubsection{Lycopene and $\beta$-Carotene}

Diethyl ether extracts from each sample were analyzed in order to estimate their lycopene and $\beta$-carotene contents by reverse-phase HPLC. The system was a Shimadzu LC-6A (Columbia, MD, USA) with a Kromasil 100A C18 column $(5 \mu \mathrm{m}, 250 \mathrm{~mm} \times 10 \mathrm{~mm}$; Phenomenex, Bologna, Italy), SPD 10A VP UV-visible detector, CR 3A recorder, SCL 10A VP system controller and Chemstation Class-VP 5.0 integration software. Immediately before injection, the diethyl ether extracts were dissolved in $2 \mathrm{~mL}$ of HPLC-grade dichloromethane and filtered with a $0.22 \mu \mathrm{m}$ PTFE syringe filter. HPLC analysis was performed using the following chromatographic conditions: Gradient elution with water (A) and acetone (B), 25\%/75\% (v/v) A/B for $15 \mathrm{~min}, 5 \% / 95 \%$ A/B for $12 \mathrm{~min}, 100 \%$ $\mathrm{B}$ for $5 \mathrm{~min}$, and then return to starting condition in $5 \mathrm{~min}$ before next injection; flow rate, $3 \mathrm{~mL} \mathrm{~min}^{-1}$; wave length of UV detector, $450 \mathrm{~nm}$, sensitivity adjusted to 0.04 AUFS (absorbance units full scale); room temperature. Solutions of standards (Lycopene and $\beta$-carotene by Sigma-Aldrich, Via Monte Rosa, 93,20149 Milano, Italy) were prepared at concentration of $1 \mathrm{mg} \mathrm{mL}^{-1}$. The lycopene and $\beta$-carotene in each sample were identified by comparison of the retention times, and by co-injection with standards.

\subsection{Statistical Analysis}

All measurements were carried out in triplicate and results were statistically analyzed using GraphPad Prism 5.0 software to determine the mean \pm standard error of the mean (SEM) of at least three technical measurements. Statistical significance was assessed by one-way analysis of variance (ANOVA), and Tukey's multiple comparison test was used to obtain $p$ values. Differences were considered significant at $p<0.05$.

\section{Results}

The EM treatment (Bokashi plus EM-1), which was applied to the soil and then during the growth of tomato plants significantly affected the productivity of San Marzano Antico and Brandywine varieties, including the number and weight of the fruits (Table 1). No marked differences were detected for Corbarino Giallo and S. Marzano Cirio 3 between BIODIN and BOK+EM treatments (Tables S1 and S2).

The total yield expressed as $\mathrm{Kg}$ of fruits was improved by BIODIN and BOK+EM treatments in comparison with control. However, the use of EM technologies enhanced the yield of about $20 \%$, more than BIODIN treatment. In particular, the improvement with $\mathrm{BOK}+\mathrm{EM}$ was observed in the total number of fruits and in their weight.

Fruits of all varieties were further investigated for their chemical-physical parameters [21]. For all varieties, no relevant differences were detected between the treatments CONTR, BIODIN, and BOK+EM (Table 2 and Table S3). 
Table 1. Production data of San Marzano Antico and Brandywine tomato varieties.

\begin{tabular}{|c|c|c|c|c|c|c|c|c|c|c|}
\hline \multirow{2}{*}{ TREATMENT } & \multicolumn{2}{|c|}{$\begin{array}{l}\text { Total Yield } \\
\quad(\mathrm{kg})\end{array}$} & \multicolumn{2}{|c|}{ Total Number of Fruits } & \multicolumn{2}{|c|}{$\begin{array}{l}\text { Average Yield for Plant } \\
(\mathrm{Kg})\end{array}$} & \multicolumn{2}{|c|}{ Average Weight of Fruit (g) } & \multicolumn{2}{|c|}{$\begin{array}{c}\text { Average Number of Fruits per } \\
\text { Plant }\end{array}$} \\
\hline & $\begin{array}{c}\text { San Marzano } \\
\text { Antico }\end{array}$ & Brandywine & $\begin{array}{c}\text { San Marzano } \\
\text { Antico }\end{array}$ & Brandywine & $\begin{array}{c}\text { San Marzano } \\
\text { Antico }\end{array}$ & Brandywine & $\begin{array}{c}\text { San Marzano } \\
\text { Antico }\end{array}$ & Brandywine & $\begin{array}{c}\text { San Marzano } \\
\text { Antico }\end{array}$ & Brandywine \\
\hline CONTR & $44.23(\mathrm{a}) *$ & 53.07 (a) & $774 \pm 8.0(\mathrm{a})$ & $929 \pm 10$ (a) & $0.79 \pm 0.48(\mathrm{a})$ & $0.95 \pm 0.58(\mathrm{a})$ & $51.6 \pm 18.7(\mathrm{a})$ & $61.9 \pm 22.5(\mathrm{a})$ & $14.4 \pm 7.2(\mathrm{a})$ & $17.3 \pm 8.6(\mathrm{a})$ \\
\hline BIODIN & $101.67(b)^{*}$ & $122.00(b)$ & $1607 \pm 12(b)$ & $1928 \pm 14(b)$ & $1.85 \pm 0.71(b)$ & $2.22 \pm 0.85(b)$ & $64.4 \pm 9.4(b)$ & $77.3 \pm 11.4(b)$ & $27.3 \pm 7.9(b)$ & $32.8 \pm 9.5(b)$ \\
\hline $\mathrm{BOK}+\mathrm{EM}$ & $123.80(\mathrm{c})^{*}$ & $148.56(\mathrm{c})$ & $1897 \pm 11$ (c) & $2276 \pm 13(\mathrm{c})$ & $1.96 \pm 1.14(b)$ & $2.35 \pm 1.37(b)$ & $74.5 \pm 15.3(b)$ & $89.5 \pm 18.4(b)$ & $25.3 \pm 12.1(b)$ & $30.4 \pm 14.5(b)$ \\
\hline
\end{tabular}

Results are expressed as mean \pm SEM. * Letters in brackets indicate the significance for $p<0.05$ (different letters indicate average values statistically different).

Table 2. Total soluble solids (TSS) content, $\mathrm{pH}$, and total titratable acidity (TA) of San Marzano Antico and Brandywine tomato varieties.

\begin{tabular}{|c|c|c|c|c|c|c|c|c|}
\hline \multirow{2}{*}{ TREATMENT } & \multicolumn{2}{|c|}{$\mathrm{pH}$} & \multicolumn{2}{|c|}{$\begin{array}{c}\text { TSS } \\
\left({ }^{\circ} \text { BRIX) }\right.\end{array}$} & \multicolumn{2}{|c|}{$\begin{array}{c}\text { TA } \\
(\mathrm{g} \mathrm{CA} / 100 \mathrm{gFW})\end{array}$} & \multicolumn{2}{|c|}{$\begin{array}{l}\text { Maturity } \\
\text { Index } \\
\text { (TSS/TA) }\end{array}$} \\
\hline & $\begin{array}{c}\text { San Marzano } \\
\text { Antico }\end{array}$ & Brandywine & $\begin{array}{c}\text { San Marzano } \\
\text { Antico }\end{array}$ & Brandywine & $\begin{array}{c}\text { San Marzano } \\
\text { Antico }\end{array}$ & Brandywine & $\begin{array}{c}\text { San Marzano } \\
\text { Antico }\end{array}$ & Brandywine \\
\hline CONTR & $4.40 \pm 0.14$ & $4.37 \pm 0.15$ & $5.05 \pm 0.76(\mathrm{a}) *$ & $5.03 \pm 0.72(\mathrm{a})$ & $0.32 \pm 0.05(\mathrm{a})$ & $0.32 \pm 0.05(\mathrm{a})$ & $15.66 \pm 2.02(\mathrm{a})$ & $15.63 \pm 2.00(\mathrm{a})$ \\
\hline BIODIN & $4.36 \pm 0.08$ & $4.32 \pm 0.06$ & $4.36 \pm 0.45(b)$ & $4.32 \pm 0.43(\mathrm{~b})$ & $0.29 \pm 0.04(b)$ & $0.27 \pm 0.04(b)$ & $15.31 \pm 2.36(\mathrm{a})$ & $15.27 \pm 2.35(\mathrm{a})$ \\
\hline $\mathrm{BOK}+\mathrm{EM}$ & $4.43 \pm 0.11$ & $4.40 \pm 0.14$ & $5.24 \pm 0.28(\mathrm{a})$ & $5.23 \pm 0.27(\mathrm{a})$ & $0.27 \pm 0.02(b)$ & $0.25 \pm 0.02(b)$ & $19.69 \pm 2.08(b)$ & $19.64 \pm 2.06(b)$ \\
\hline
\end{tabular}

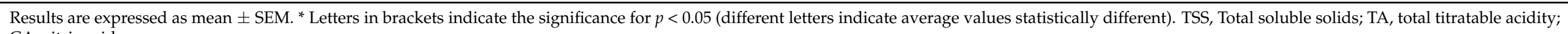
CA, citric acid. 
All samples were extracted with different solvents with the aim to evaluate the antioxidant activity of different fractions: hydrophilic, lipophilic, and methanolic. The amount of lipophilic extracts ranged between $34.4 \mathrm{mg} 100 \mathrm{~g}^{-1}$ fresh product (San Marzano Cirio $3+\mathrm{EM}$ ) and $77.9 \mathrm{mg} 100 \mathrm{~g}^{-1}$ fresh product (Corbarino Giallo), while the amount of methanolic extracts ranged between $489.9 \mathrm{mg}_{100 \mathrm{~g}^{-1}}$ fresh product (San Marzano Antico+EM) and $1161,7 \mathrm{mg} 100 \mathrm{~g}^{-1}$ fresh product (Corbarino Giallo). No significant differences were detected in hydrophilic fraction and $\mathrm{pH}$, and none correlation between different treatments and yield of extracts was found (Table S4).

The total antioxidant activity related to hydrophilic, methanolic, and lipophilic fractions was evaluated by using DMPD, DPPH, and ABTS methods, respectively.

The antioxidant activity, related to different extracts of samples and expressed as $\mathrm{mg}$ Trolox100 $\mathrm{g}^{-1}$ of fresh product, is reported in Figure 1A-C.
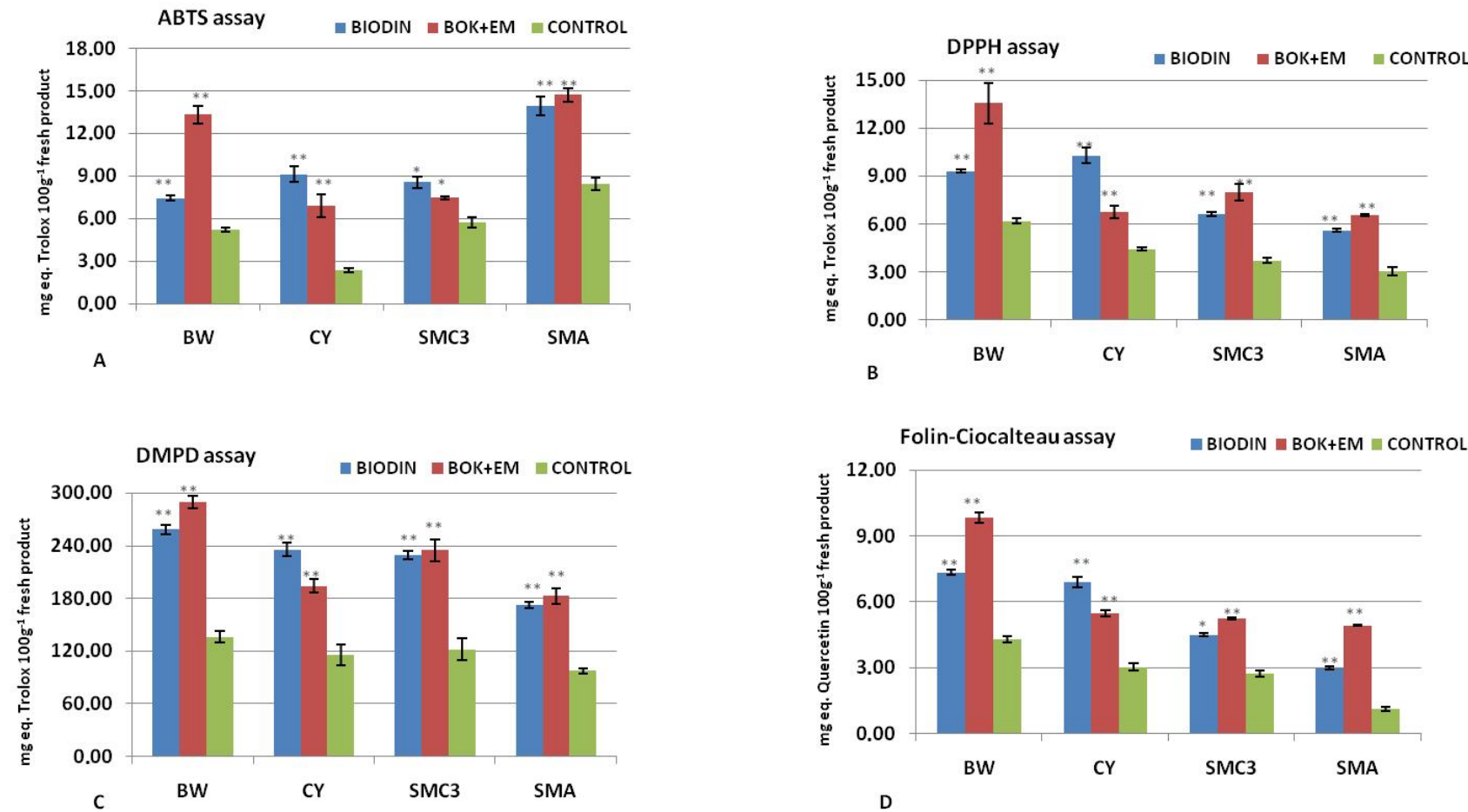

Figure 1. Antioxidant activity of lipophilic (A), methanolic (B), and hydrophilic (C) extracts evaluated by means of ABTS, DPPH, and DMPD methods, respectively. Polyphenol content (D) was evaluated by using the Folin-Ciocalteau method. BW (Brandywine), CY (Corbarino Giallo), SMC3 (San Marzano Cirio 3), SMA (San Marzano Antico). Results are shown as mean of three different measurements \pm SD. Statistical analysis was performed by subjecting data from the two different treatments BIODIN and BOK+EM versus CONTROL to Student's $t$-test. Statistically significant differences are indicated with: * significant $(p<0.05)$ and ${ }^{* *}$ very significant $(p<0.01)$.

Data showed that among all varieties, Brandywine and San Marzano Antico treated with $\mathrm{BOK}+\mathrm{EM}$ revealed an increase of antioxidant capacity in the three fractions (lipophilic A, methanolic B, and hydrophilic C) compared with CONTROL and BIODIN treatments. The increase was significantly marked in Brandywine variety both for lipophilic extract (an increment of more than 70\%) and methanolic fraction (an increment of more than $40 \%$ ). Results of the Folin Ciocalteau assay (Figure 1D) performed on all samples, indicated a major polyphenol contents in Brandywine and San Marzano Antico varieties treated with $\mathrm{BOK}+\mathrm{EM}$ ( 9.83 and $4.92 \mathrm{mg}$ eq. quercetin $100 \mathrm{~g}^{-1}$ fresh product, respectively) compared with the same varieties treated with CONTROL and traditional method BIODIN (7.34 and $2.98 \mathrm{mg}$ eq. quercetin $100 \mathrm{~g}^{-1}$ fresh product for BW and SMA, respectively). The enhancement in bioactive compound content was also confirmed by HPLC analysis, which was performed on the lipophilic extracts of each sample (Table 3). In particular, especially 
in Brandywine variety but also in San Marzano Antico, an increase in lycopene and $\beta$ carotene amounts was registered. These results are in agreement with the best antioxidant potential observed in lipophilic extracts of Brandywine and San Marzano Antico varieties.

Table 3. Lycopene and $\beta$-carotene contents in lipophilic extracts of tomatoes obtained by HPLC analysis.

\begin{tabular}{|c|c|c|}
\hline Samples & $\begin{array}{c}\text { Lycopene } \\
\text { (mg } 100 \mathrm{~g}^{-1} \text { Fresh product) }\end{array}$ & $\begin{array}{c}\beta \text {-Carotene } \\
\left(\mathrm{mg} 100 \mathrm{~g}^{-1} \text { Fresh Product) }\right.\end{array}$ \\
\hline Brandywine CONTR & $20.16 \pm 1.5(\mathrm{a}) *$ & $8.32 \pm 0.7(\mathrm{a})$ \\
\hline Brandywine BIODIN & $30.79 \pm 1.8(\mathrm{~b})$ & $13.68 \pm 1.3(b)$ \\
\hline Brandywine + EM-1 & $35.25 \pm 1.6(\mathrm{~b})$ & $32.90 \pm 1.9(\mathrm{c})$ \\
\hline Corbarino giallo CONTR & n.d. & $15.62 \pm 1.1(\mathrm{a})$ \\
\hline Corbarinogiallo BIODIN & $3.89 \pm 0.4(a)$ & $46.76 \pm 2.3(b)$ \\
\hline Corbarinogiallo + EM-1 & $3.34 \pm 0.4(\mathrm{a})$ & $26.70 \pm 1.8(\mathrm{c})$ \\
\hline San Marzano Cirio 3 CONTR & $9.87 \pm 0.8(\mathrm{a})$ & $3.25 \pm 1.1(\mathrm{a})$ \\
\hline San Marzano Cirio 3 BIODIN & $23.15 \pm 1.6(b)$ & $13.89 \pm 1.2(\mathrm{~b})$ \\
\hline San Marzano Cirio 3 + EM-1 & $14.47 \pm 1.2(\mathrm{c})$ & $7.23 \pm 0.8(\mathrm{c})$ \\
\hline San Marzano Antico CONTR & $10.26 \pm 1.3(\mathrm{a})$ & $4.04 \pm 0.6(\mathrm{a})$ \\
\hline San Marzano Antico BIODIN & $18.33 \pm 1.5(\mathrm{~b})$ & $7.33 \pm 0.6(b)$ \\
\hline San Marzano Antico + EM-1 & $18.40 \pm 1.4(\mathrm{~b})$ & $8.22 \pm 0.9(b)$ \\
\hline
\end{tabular}

Results are expressed as mean \pm SEM. * Letters in brackets indicate the significance for $p<0.05$ (different letters indicate average values statistically different between different treatments for each tomato variety). n.d. not detected.

\section{Discussion}

The optimization of tomato cultivation through a reduction of chemical fertilizers and pesticides is a topic of growing interest. A recent study reported that bacterial strains residing in the rhizosphere and endophytes of different tomato cultivars showed plant growth-promoting (PGP) abilities in vitro, which make them potentially applicable to eco-friendly fertilizing systems based on microbial inoculation [25].

The beneficial effects of microbial inoculation on the growth, yield, and nutritional parameters of tomato have been discussed by Berger et al. (2017) [26]. They reported an increased plant yield production and also taste-affecting compounds during the ripening process in tomato plants inoculated with the plant growth-promoting bacterium (PGPB) Kosakonia radicincitans.

One of the most ancient eco-friendly strategy in agriculture is the Biodynamic Agriculture. This methodology is based on nitrogen fixation by leguminoses, a crop rotation, and the use of organic, mostly composted, solid manure. The use of biodynamic agriculture can bring multiple benefits to tomato crops, both in terms of biometric parameters of the plant (plant height, fruit yield, etc.), and in the improvement of fruit quality [19]. Results reported in the present paper confirmed the efficiency of biodynamic treatment in tomato cultivation. Indeed, the productivity and nutritional qualities of all investigated tomato varieties grown with BIODIN treatment were improved compared to CONTROL treatment.

In previous papers, Higa described, for the first time, different pools of beneficial microorganisms, containing more than 80 species (photosynthetic bacteria, lactic acid bacteria, yeasts, actinomycetes, etc.), isolated from the soil and named effective microorganisms (EM), presenting their use in agriculture [20,27].

According to the data reported in literature, the present study, conducted on tomato plants, confirm the positive effects of EM inoculation on the growth of plants and nutritional aspect of fruits, in term of antioxidant activity. The benefits of EM technology have been assigned to several factors, such as the release of nutrients from Bokashi (EM plus organic matter), an improved photosynthesis, a major production of bioactive substances (such as hormones and enzymes), controlling soil diseases and accelerating the decomposition of lignin materials in the soil [28]. 
These factors could affect the biosynthesis of secondary metabolites, including polyphenols and carotenoids; then, an enhancement of antioxidant activity as well as bioactive metabolite contents were observed in some of the investigated tomato varieties. Previous papers revealed the role of EM compost as soil supplements, to obtain several benefits to tomato crop, both in terms of plant biometric parameters (plant height, fruit yield, etc.), and also increasing the fruit quality in terms of lycopene and Vitamin C contents, antioxidant activity, and defense enzyme activities [29,30]. The present study also suggested that the application of EM technology could improve the content of bioactive compounds in tomato fruits, in particular of polyphenols as resulted by Folin-Ciocalteau and DPPH methods. However, lipophilic and hydrophilic compounds also changed in their content or composition in light of an increased antioxidant activity estimated by ABTS and DMPD methods.

Since the first report [20], the scientific interest towards the use of EM in crop production has increased and its beneficial effects has been reported. In particular, a very interesting paper described the findings of a long-term field experiment for soil fertility and crop yield improvement by using effective microorganisms on wheat, one of the most important food crops in China [31]. The wheat straw biomass as well as grain yields and straw and grain nutrition parameters significantly increased when treated with EM technology compared with untreated samples. Similar results were achieved on apple, pea, rice, bean, soybean, and cotton plants [32-37]. Our results also confirm that the use of EM technologies enhanced the yield of crop production. In particular, an improvement of tomato fruits yield of about $20 \%$, more than BIODIN treatment, was observed.

However, the use of EM technology did not have similar effects on investigated tomato varieties. A previous paper reported a study performed on bacterial strains isolated from different tomato cultivars. Among the total of 23 isolates, 11 were rhizospheric strains, residing in the rhizosphere (soil) or phyllosphere (the aerial habitat influenced by plants), and 12 were endophytic strains that reside in specific tissues of the plant (such as root cortex or xylem) and develop a close association with the plant, with exchange of nutrients, enzymes, functional agents and also "signals" [25]. Therefore, given that the soil and aerial condition were the same for investigated tomato varieties, their different behavior to EM technology could be linked to different endophytic microbial population that could act synergistically or not with EM.

Other beneficial effects of EM technology reported in literature were not limited to plant growth but also to composting process, waste treatment (water and solid), and phenol degradation [38-42].

\section{Conclusions}

The research of novel bio-based technology in agriculture is necessary both for ensuring soil quality and harvest protection, and for eco-sustainable production system by the reduction of consumption of chemical fertilizers and synthetic pesticides.

In conclusion, this study showed that the application of EM technology in agriculture represent a very promising eco-friendly strategy for increase crop production and for the enhancement in yield and healthy quality of crops.

Supplementary Materials: The following are available online at https:/ / www.mdpi.com/2077-0 472/11/2/112/s1, Table S1. Production data of San Marzano Cirio 3 tomato variety. Table S2. Production data of Corbarino Giallo tomato variety. Table S3. Total soluble solids (TSS) content, pH and total titratable acidity (TA) of San Marzano Cirio 3 and Corbarino Giallo tomato varieties. Table S4. Overview table of tomato extraction steps.

Author Contributions: Conceptualization, G.T. and R.D.P.; data curation, G.R.A. and C.I.; formal analysis, C.D. and C.I.; investigation, G.R.A. and A.P.; methodology, R.D.P.; resources, R.D.P.; supervision, G.T., B.N. and R.D.P.; visualization, C.D.; writing-original draft, G.T., G.R.A. and R.D.P.; writing-review and editing, G.T., B.N. and A.P. All authors have read and agreed to the published version of the manuscript. 
Funding: This research received no external funding.

Institutional Review Board Statement: Not applicable.

Informed Consent Statement: Not applicable.

Acknowledgments: The authors wish to thank EM-SCHWEIZ AG (Switzerland) for providing EM products. Moreover, the authors are grateful to "Società Agricola Accadia Verde s.r.l.", Accadia (FG, Italy) for having made available the experimental fields for our research.

Conflicts of Interest: The authors declare no conflict of interest.

\section{References}

1. United Nations, Department of Economic and Social Affairs, Population Division. World Population Prospects 2019: Highlights (ST/ESA/SER.A/423); Sales No.: E.19.XIII.4; United Nations, Department of Economic and Social Affairs, Population Division: New York, NY, USA, 2019; ISBN 978-92-1-148316-1.

2. Rockstrom, J.; Williams, J.; Daily, G.; Noble, A.; Matthews, N.; Gordon, L.; Wetterstrand, H.; DeClerck, F.; Shah, M.; Steduto, P.; et al. Sustainable intensification of agriculture for human prosperity and global sustainability. AMBIO 2017, 46, 4-17. [CrossRef] [PubMed]

3. Motesharezadeh, B.; Etesami, H.; Bagheri-Novair, S. and Amirmokri, H. Fertilizer consumption trend in developing countries vs. developed countries. Environ. Monit. Assess. 2017, 189, 103. [CrossRef] [PubMed]

4. Machiwal, D.; Jha, M.K.; Singh, V.P.; Mohan, C. Assessment and mapping of groundwater vulnerability to pollution: Current status and challenges. Earth Sci. Rev. 2018, 185, 901-927. [CrossRef]

5. Yang, Y.; Lian, X.Y.; Jiang, Y.H.; Xi, B.D.; He, X.S. Risk-based prioritization method for the classification of groundwater pesticide pollution from agricultural regions. Integr. Environ. Assess. Manag. 2017, 13, 1052-1059. [CrossRef]

6. Giannadaki, D.; Giannakis, E.; Pozzer, A.; Lelieveld, J. Estimating health and economic benefits of reductions in air pollution from agriculture. Sci. Total Environ. 2018, 622, 1304-1316. [CrossRef]

7. Savci, S. An Agricultural Pollutant: Chemical Fertilizer. Int. J. Environ. Sci. Dev. 2012, 3, 77-80. [CrossRef]

8. Mahanty, T.; Bhattacharjee, S.; Goswami, M.; Bhattacharyya, P.; Das, B.; Ghosh, A.; Tribedi, P. Biofertilizers: A potential approach for sustainable agriculture development. Environ. Sci. Pollut. Res. 2017, 24, 3315-3335. [CrossRef]

9. Vejan, P.; Abdullah, R.; Khadiran, T.; Ismail, S.; Boyce, A.N. Role of Plant Growth Promoting Rhizobacteria in Agricultural Sustainability-A Review. Molecules 2016, 21, 573. [CrossRef]

10. Olanrewaju, O.S.; Glick, B.R.; Babalola, O.O. Mechanisms of action of plant growth promoting bacteria. World J. Microbiol. Biotechnol. 2017, 33, 197. [CrossRef] [PubMed]

11. Tommonaro, G.; De Prisco, R.; Abbamondi, G.R.; Nicolaus, B. Bioactivity of Tomato Hybrid Powder: Antioxidant Compounds and Their Biological Activities. J. Med. Food 2013, 16, 351-356. [CrossRef] [PubMed]

12. Tommonaro, G.; Caporale, A.; De Martino, L.; Popolo, A.; De Prisco, R.; Nicolaus, B.; Abbamondi, G.R.; Saturnino, C. Antioxidant and cytotoxic activities investigation of tomato seed extracts. Nat. Prod. Res. 2014, 28, 764-768. [CrossRef] [PubMed]

13. Farinetti, A.; Zurlo, V.; Manenti, A.; Coppi, F.; Mattioli, A.V. Mediterranean diet and colorectal cancer: A systematic review. Nutrition 2017, 43-44, 83-88. [CrossRef] [PubMed]

14. Chaudhary, P.; Sharma, A.; Singh, B.; Nagpal, A.K. Bioactivities of phytochemicals present in tomato. J. Food Sci. Technol. 2018, 55, 2833-2849. [CrossRef]

15. Tommonaro, G.; De Prisco, R.; Abbamondi, G.R.; Marzocco, S.; Saturnino, C.; Poli, A.; Nicolaus, B. Evaluation of Antioxidant Properties, Total Phenolic Content, and Biological Activities of New Tomato Hybrids of Industrial Interest. J. Med. Food 2012, 15, 483-489. [CrossRef] [PubMed]

16. Ilahy, R.; Siddiqui, M.W.; Tlili, I.; Montefusco, A.; Piro, G.; Hdider, C.; Lenucci, M.S. When Color Really Matters: Horticultural Performance and Functional Quality of High-Lycopene Tomatoes. Crit. Rev. Plant Sci. 2018, 37, 15-53. [CrossRef]

17. Barone, D.; Cito, L.; Tommonaro, G.; Abate, A.A.; Penon, D.; De Prisco, R.; Penon, A.; Forte, I.M.; Benedetti, E.; Cimini, A.; et al. Antitumoral Potential, Antioxidant Activity and Carotenoid Content of Two Southern Italy Tomato Cultivars Extracts: San Marzano and Corbarino. J. Cell. Physiol. 2018, 233, 1266-1277. [CrossRef]

18. Strazzullo, G.; De Giulio, A.; Tommonaro, G.; La Pastina, C.; Saturnino, C.; Poli, A.; Nicolaus, B.; De Prisco, R. Anti-oxidative activity and lycopene and $\beta$-carotene contents in different cultivars of tomato (Lycopersicon esculentum). Int. J. Food Prop. 2007, 10, 321-329. [CrossRef]

19. Sharma, A.B. An introduction to biodynamic approach in agriculture. Asian J. Home Sci. 2012, 7, 616-621.

20. Higa, T. Effective microorganisms: A biotechnology for mankind. In Proceedings of the First International Conference on Kyusei Nature Farming, Khon Kaen, Thailand, 17-21 October 1989; Parr, J.F., Hornick, S.B., Whitman, C.E., Eds.; U.S. Department of Agriculture: Washington, DC, USA, 1991; pp. 8-14.

21. Caliman, F.R.B. Quality of tomatoes grown under a protected environment and field conditions. Idesia $2010,28,75-82$.

22. Fogliano, V.; Verde, V.; Randazzo, G.; Ritieni, A. Method for measuring antioxidant activity and its application to monitoring the antioxidant capacity of wines. J. Agric. Food Chem. 1999, 47, 1035-1040. [CrossRef] 
23. Miller, N.J.; Sampson, J.; Candeias, L.P.; Bramley, P.M.; RiceEvans, C.A. Antioxidant activities of carotenes and xanthophylls. FEBS Lett. 1996, 384, 240-242. [CrossRef]

24. Blois, M. Antioxidant Determinations by the Use of a Stable Free Radical. Nature 1958, 181, 1199-1200. [CrossRef]

25. Abbamondi, G.R.; Tommonaro, G.; Weyens, N.; Thijs, S.; Sillen, W.; Gkorezis, P.; Iodice, C.; Rangel, W.D.; Nicolaus, B.; Vangronsveld, J. Plant growth-promoting effects of rhizospheric and endophytic bacteria associated with different tomato cultivars and new tomato hybrids. Chem. Biol. Technol. Agric. 2016, 3, 1-10. [CrossRef]

26. Berger, B.; Baldermann, S.; Ruppel, S. The plant growth-promoting bacterium Kosakonia radicincitans improves fruit yield and quality of Solanum lycopersicum. J. Sci. Food Agric. 2017, 97, 4865-4871. [CrossRef] [PubMed]

27. Higa, T.; Parr, J.F. Beneficial and effective microorganisms for a sustainable agriculture and environment. Int. Nat. Farming Res. Cent. 1994, 808, 1-16.

28. Daly, M.J.; Stewart, D.P.C. Influence of "effective microorganisms" (EM) on vegetable production and carbon mineralization-A preliminary investigation. J. Sustain. Agric. 1999, 14, 15-25. [CrossRef]

29. Verma, S.; Sharma, A.; Kumar, R.; Kaur, C.; Arora, A.; Shah, R.; Nain, L. Improvement of antioxidant and defense properties of Tomato (var. Pusa Rohini) by application of bioaugmented compost. Saudi J. Biol. Sci. 2015, 22, 256-264. [CrossRef]

30. Xu, H.L.; Wang, R.; Mridha, M. Effects of organic fertilizers and a microbial inoculant on leaf photosynthesis and fruit yield and quality of tomato plants. J. Crop Prod. 2000, 3, 173-182. [CrossRef]

31. Hu, C.; Qi, Y.C. Long-term effective microorganisms application promote growth and increase yields and nutrition of wheat in China. Eur. J. Agron. 2013, 46, 63-67. [CrossRef]

32. Kusznierewicz, B.; Lewandowska, A.; Martysiak-Zurowska, D.; Bartoszek, A. The influence of plant protection by effective microorganisms on the content of bioactive phytochemicals in apples. J. Sci. Food Agric. 2017, 97, 3937-3947. [CrossRef]

33. Javaid, A. Foliar application of effective microorganisms on pea as an alternative fertilizer. Agron. Sustain. Dev. 2006, 26, 257-262. [CrossRef]

34. Javaid, A. Effects of biofertilizers combined with different soil amendments on potted rice plants. Chil. J. Agric. Res. 2011, 71, 157-163. [CrossRef]

35. Javaid, A.; Bajwa, R. Field evaluation of effective microorganisms (EM) application for growth, nodulation, and nutrition of mung bean. Turk. J. Agric. For. 2011, 35, 443-452.

36. Javaid, A.; Mahmood, N. Growth, nodulation and yield research of soybean to biofertilizers and organic manures. Pak. J. Bot. 2010, 42, 863-871.

37. Khaliq, A.; Abbasi, M.K.; Hussain, T. Effects of integrated use of organic and inorganic nutrient sources with effective microorganisms (EM) on seed cotton yield in Pakistan. Bioresour. Technol. 2006, 97, 967-972. [CrossRef]

38. Formowitz, B.; Elango, F.; Okumoto, S.; Muller, T.; Buerkert, A. The role of "effective microorganisms" in the composting of banana (Musa ssp.) residues. J. Plant Nutr. Soil Sci. 2007, 170, 649-656. [CrossRef]

39. Van Fan, Y.; Lee, C.T.; Klemes, J.J.; Chua, L.S.; Sarmidi, M.R.; Leow, C.W. Evaluation of Effective Microorganisms on home scale organic waste composting. J. Environ. Manag. 2018, 216, 41-48. [CrossRef]

40. Shalaby, E.A. Prospects of effective microorganisms technology in wastes treatment in Egypt. Asian Pac. J. Trop. Biomed. 2011, 1, 243-248. [CrossRef]

41. Park, G.S.; Khan, A.R.; Kwak, Y.; Hong, S.J.; Jung, B.; Ullah, I.; Kim, J.G.; Shin, J.H. An improved effective microorganism (EM) soil ball-making method for water quality restoration. Environ. Sci. Pollut. Res. Int. 2016, 23, 1100-1107. [CrossRef]

42. Sivasubramanian, S.; Namasivayam, S.K.R. Evaluation of phenol degradation by effective microorganism (EM) technology with EM-1. Afr. J. Microbiol. Res. 2013, 7, 4117-4122. 